\title{
Uma percepção do olhar: os três paradigmas da imagem à luz da semiótica peirceana
}

Rosane Silva

Professora e assistente de edicãa. Mestranda em Estudos Comparados de Literaturas de Lingua Portuguesa pela Universidade de São Paulo.

E-mail: rosaneasilva@yahoo.com.br

Resumo: As concepções de Charles Peirce sobre Semiótica e seus estudos acerca da Percepção nos permitem fazer uma leitura das imagens nas mais diversas formas de criação e cruzar esse tipo de linguagem com outros modos de expressão em uma relação ilimitada de possibilidades. Signos que vão se recriando à luz do interpretante, formando uma "colméia" que abraça inúmeras interpretações do olhar. No esteio dessas teorias é feita a análise do cruzamento das imagens de Scatamacchia com o poema A princesa Raga-Si, de José Arrabal, segundo a Semiótica peirceana.

Palavras-chave: Peirce, Semiótica, Percepção, paradigmas da imagem, A princesa Raga-Si.
Abstract: Charles Peirce's conceptions about Semiotic and his studies on the subject about Perception to allow us reading at the images with a lot of creation shapes and we can cross this kind of the language with another expression way like ilimited possibility. Signs that produce itself to become known to the interpreter and it create a beehive that it gathers several interpretations way of seeing. And this support of the teories we are going to do the intersection analysis of the images in the poem called The princess Raga-Si, by José Arrabal.

Keywords: Peirce, Semiotic, Perception, paradigms of the images, The princess Raga-Si.

As imagens estão divididas em dois domínios: o domínio das representações visuais - desenhos, pinturas, gravuras, fotografias, imagens cinematográficas, televisivas, holográficas e infográficas - e o domínio das representações mentais - visões, fantasias, imaginações, modelos. Neste artigo, vamos focalizar o estudo das imagens no domínio da representação visual, que estão centradas na representação por semelhança, ou seja, signos que representam algo do mundo visível ou signos que se apresentam em si mesmos, o que nos leva, à luz da semiótica peirceana, a diferenciar ícone de signo icônico (ou hipoícones), uma vez que Peirce fez uma diferença clara entre ambos, conceituando hipoícones como signo que se traduz na relação de semelhança que mantém com seu objeto.

Recebido: 13/9/2007

Aprovado: 17/9/2007 
comunicação \& educação • Ano XIII • Número 3 • set/dez 2008

\section{TUDO É SIGNO}

Charles Sanders Peirce (1839-1914) foi cientista, matemático, historiador, filósofo e, desde cedo, soube que sua vocação estava voltada para a Lógica. Estudioso de vários campos do conhecimento, ele tinha uma visão pragmática do mundo e, durante os quarenta anos de trabalho, identificou a Lógica com a Semiótica, pois para ele toda interpretação é signo. Seu trabalho intelectual foi empreendido a fim de traçar os princípios fundamentais dos métodos aplicados nas Ciências. Se o pensamento é a manifestação do conhecimento e o conhecimento busca a verdade, é necessário delinear as regras para o exercício do pensar, de modo a garantir procedimentos corretos para argumentações que culminam em conclusões sustentadas em evidências - conclusões que não são infalíveis e estão sujeitas às correções e revisões.

Peirce $^{1}$ reconheceu na Lógica dos pensamentos filosófico e científico a Semiótica, pois bastava substituir a noção de evidência pela concepção de signo, muito mais ampla. Ele, então, debruçou-se sobre o estudo da concepção de signo e percebeu que signo não é tão-somente fundamental para a Ciência, mas fundamental, também, para a Linguagem, a Arte, a Política, a Religião. A concepção de signo é a base para o pensamento, a ação, a percepção e a emoção. Ele defendeu que "[...] o signo é aquilo que nos adianta o conhecimento, [...] e todo o nosso conhecimento e pensamento se realizam por signos" ${ }^{2}$.

Ao defender que Semiótica e Lógica são a mesma coisa, Peirce passou a elaborar a sua doutrina das categorias e concluiu que há três elementos universais presentes em qualquer fenômeno: primeiridade, secundidade e terceiridade. Essas categorias foram usadas para distinguir: as três espécies de representações ou signos (ícone, índice e símbolo); as três ciências concebíveis (Gramática formal, Lógica e Retórica); a divisão geral dos símbolos (termos, proposições e argumentos); os três tipos de argumentos (dedução, indução e abdução). As definições e classificações de signo conduzem à análise da semiose $^{3}$, ou seja, da ação do signo nos textos literários, nos filmes, nas peças de teatro, nas peças publicitárias, nas obras de arte, nos fatos históricos, nos sonhos, entre outros.

\section{OS TRÊS PARADIGMAS DA IMAGEM}

Desde as pinturas pré-históricas nas cavernas, criadas muito antes da invenção da escrita, as imagens são meios de expressão da cultura humana. Diferentemente do universo da palavra, não se criou um suporte de estudos para o universo imagético. Mesmo nos anos 1960, quando a Semiologia se voltou para outros fenômenos sígnicos fora da Lingüística, as imagens analisadas eram aquelas acompanhadas de textos verbais ${ }^{4}$.

A partir das considerações de Santaella e Nöth, é possível fazer análise da Semiótica da imagem, da fotografia e da pintura do ponto de vista da relação das imagens com seus objetos, ou a que se referem, pois os autores partem da 
Uma percepção do olhar - Rosane Silva

premissa de que as imagens podem ser tanto ícones, índices ou símbolos, e o que vai diferenciá-las são as manifestações predominantes. Portanto, há:

- o protótipo da imagem icônica - a pintura não-figurativa (abstrata);

- o protótipo da imagem indexical - a fotografia e a pintura realista; e

- o protótipo da imagem simbólica - a pintura iconológica ou iconográfica.

Nesse sentido, é preciso ter em mente que a passagem (histórica) de um paradigma a outro não acontece de forma repentina e todos os critérios analisados não se modificam concomitantemente. Trata-se, portanto, de uma passagem gradativa.

No processo evolutivo de produção da imagem, Santaella e Nöth propõem a existência de três paradigmas da imagem, cujas divisões resultaram de critérios de perspectiva materialista, em que cada paradigma foi analisado a partir dos modos de produção (materiais, instrumentos, técnicas, meios e mídias). São eles:

- pré-fotográfico: a característica básica desse paradigma é o modo de produção artesanal, dependente de um suporte para servir de receptador às substâncias - na maioria das vezes esse suporte são as tintas -, em que um agente produtor vai registrar nele o seu gesto através de instrumento (o movimento das mãos), e o pincel é a extensão dos dedos do artista. $\mathrm{O}$ resultado desse gesto não será uma imagem, mas um objeto único e original criado por um agente demiurgo, que pousou seu olhar em um instante raro e sagrado e deu forma àquele olhar. Esse paradigma é um processo monádico, no qual se incorporam, em uma ação indissociável, o sujeito-criador, o objeto-criado e a fonte de criação. Entram nesse paradigma as imagens nas pedras e nas rochas, o desenho, a pintura e a escultura;

- fotográfico: a grande inovação nesse paradigma são os processos automáticos de captação da imagem, através de uma técnica ótica em que a emanação da luz produz a imagem. O suporte é um fenômeno químico ou eletromagnético. Afasta-se a mão do pintor para entrar o olho do sujeito, prolongado no olho da lente para confrontar o real a ser capturado. É um processo diádico (olho do sujeito + o real). A imagem fixada na revelação é vestígio do real, um hiato, um recorte eternizado de um instante furtado, um arquivo para a posteridade, em que um momento vivo foi fixado e congelado no ato do disparo do flash; uma imagemtestemunha de um instante que não mais voltará, porque ele se foi;

- pós-fotográfico: o meio de produção da imagem, nesse paradigma, é uma prótese ótica, fruto das invenções tecnológicas ocorridas nos séculos XIX e XX. O suporte técnico já se apresenta como processo triádico na composição das imagens, pois resulta da união entre o computador e uma tela de vídeo, mediados por um programa de cálculos matemáticos. O agente de produção é o programador, não um artista, "cuja inteligência visual se realiza na interação e complementaridade com os poderes da inteligência artificial”. São imagens transformadas a partir de uma matriz

5. PEIRCE, Os pensadores, op. cit., nota 4 p. 166. 
comunicação \& educação • Ano XIII • Número 3 • set/dez 2008

de números em pontos elementares (pixels), visualizadas sobre uma tela de vídeo. Imagem sintética que prescinde do real empírico e busca a simulação da realidade com toda sua profundidade; a mudança fundamental trazida para esse meio de produção foi a possibilidade de simular experiências sobre um objeto (do real) fora do tempo e do espaço.

Essa divisão da imagem em três paradigmas, a partir dos meios de produção, leva à análise dos seguintes critérios:

- os meios de armazenamento das imagens;

- o papel do agente produtor;

- a natureza das imagens em si mesmas;

- as imagens e o mundo;

- os meios de transmissão; e

- o papel do receptor.

Essas divisões e seus critérios permitem estudar as mudanças e as rupturas de um paradigma ao outro.

\section{ANÁLISE DOS TRÊS PARADIGMAS DA IMAGEM}

Uma das grandes mudanças na passagem de um paradigma a outro é quanto aos meios de armazenamento. $\mathrm{O}$ desgaste provocado pelo tempo era o grande desafio na preservação e na conservação das imagens. Do pré-fotográfico ao pósfotográfico, houve uma grande mudança na preservação das imagens - do perecível ao reprodutível (da fotografia), ao disponível (da imagem infográfica).

O papel do agente produtor também sofreu impactos. Do pré-fotográfico ao pós-fotográfico, ampliaram-se os conceitos de Arte em que várias maneiras de construção da imagem coexistem, simultaneamente, para um mundo que abraça diversas formas artísticas.

Quanto à natureza, as imagens artesanais são uma figuração por imitação, quando o signo produzido busca fundir o sujeito ao mundo. Já as imagens no paradigma fotográfico distanciam-se das representações para funcionar como reprodução por captação da luz, e as infográficas são simulações de modelos de objetos, em que a imagem-matriz pode funcionar como imagem-experimento.

Na relação da imagem com o mundo, temos no paradigma pré-fotográfico uma metáfora evocativa de um mundo que já não existe, porque há dentro dele, ainda, um resíduo do divino. Embora monádica, é simbólica, buscando ocultar a separação com esse mesmo mundo. No paradigma fotográfico, a imagem funciona como metonímia, ou seja, uma relação por contigüidade. É imagem-documento em que figura um recorte da captura de um instante do real. É um signo indexical. No paradigma pós-fotográfico, ela trabalha como metamorfose, pois é uma imagem experimental que navega em um real filtrado pelo cálculo. A imagem sintética vista na superfície da tela produz um signo icônico, embora seja gerada dentro das abstrações matemáticas (símbolos).

A ruptura de paradigma nos meios de transmissão está relacionada à ruptura nos meios de armazenamento. No paradigma pré-fotográfico, as imagens, 
Uma percepção do olhar • Rosane Silva

dado seu caráter único e autêntico, precisam ser conservadas em espaços que retardam os efeitos da intempérie: templos, museus, galerias (espaços reclusos, de acesso limitado). Já no fotográfico, que tem como característica a reprodução, as imagens ocupam os espaços da comunicação de massa (jornais, revistas), onde o acesso não exige o deslocamento do receptor. As imagens pós-fotográficas, cujo armazenamento é por tempo indeterminado - quase eternas -, têm natureza de disponibilidade: são acessadas por todos, em nível planetário. Seu meio de transmissão característico é a interação. Diferentemente da mass media, propaga-se por contato. É o espaço interativo.

O papel do receptor nos três paradigmas vai ser determinado pela natureza e produção. Enquanto na imagem artesanal o receptor assume o papel contemplativo, na fotográfica será um observador e, na pós-fotográfica, um sujeito de interação.

Para Santaella e Nöth, essa abordagem inserida nas três categorias de Peirce (primeiridade, secundidade e terceiridade), e desdobrada nas divisões, está em oposição ao passado, pois, atualmente, encontramos nas expressões artísticas uma mescla de paradigmas. Há criações artísticas combinando imagens artesanais, fotos, holografia e infografia - é a hibridização das Artes. O pluralismo do estilo e a mistura de técnicas (características do pós-modernismo) dirigem o olhar do agente receptivo para uma nova leitura imagética, em que podem ocorrer, simultaneamente, os três protótipos.

\section{A PERCEPÇÃO À LUZ DA SEMIÓTICA PEIRCEANA}

O olho é o órgão sensorial da visão e, com o ouvido, está conectado ao cérebro; diferentemente dos outros sentidos (olfato, paladar e tato), que se ligam às vísceras. A visão não só nos permite detectar a luz e as imagens, como também interpretá-las. Em seu sentido mais amplo, a percepção visual requer a intervenção de zonas especiais do cérebro (córtex visual) para analisar e sintetizar as informações recolhidas (forma, cor, textura, relevo). Por isso, ver é a percepção (visual) das radiações luminosas, compreendendo todo o conjunto de mecanismos fisiológicos e psicológicos, pelo qual essas radiações determinam impressões sensoriais de natureza variada, como as cores, as formas, o movimento, a distância e o relevo. Esse status da visão fez com que os estudos sobre a Percepção fossem reduzidos à percepção do visual, dando ênfase à relação entre o objeto percebido e a retina, e quase ignorando outros fatores menos explícitos, mas não menos misteriosos e interessantes na relação entre o que é percebido e a mente que percebe.

É nesse sentido que a Semiótica, segundo Peirce, supera o reducionismo dos outros estudos, pois para ele a Percepção se dá em um processo triádico, diferente das teorias que privilegiam o dualismo, nas quais há um sujeito que percebe e aquilo que é percebido. Para Peirce, a percepção é determinada pelo percepto, que está fora de nós e nos força a enfrentá-lo. Quando interpretado no julgamento da percepção, o percepto recebe o nome de percipuum. Se a Percepção 
comunicação \& educação • Ano XIII • Número 3 • set/dez 2008

é definida pelo percepto, então, este só pode ser conhecido através da mediação do signo, que é o julgamento da percepção. Quando se dá o conhecimento do percepto, surge o percipuum, ligação entre o que está fora e o juízo perceptivo, fruto de uma elaboração mental.

Amparados na teoria da percepção à luz da Semiótica peirceana e na tendência pós-modernista (adepta do hibridismo na produção de imagens), partimos para a análise do texto A princesa Raga-Si, de José Arrabal, e ilustrado por Cláudia Scatamacchia.

\section{A princesa Raga-Si}

\section{A narrativa}

É a lenda sobre uma princesa da Índia antiga - Raga-Si ${ }^{6}-$, aprisionada pelo medo em seu castelo. Um dia, apareceu um cego que lhe ensinou a admirar o mundo temido pela princesa. Nesse despertar para a vida, Raga-Si descobriu o amor.

\section{O canto encantado da Lua e do Sol}

Raga-Si é um canto à capela. Nos nomes das personagens - Raga-Si e Inayat-Sol -, estão a musicalidade do texto (si e sol), a personalidade de cada um (si - introspectiva; sol - que se mostra a todos) e a sugestão de duas almas que se completam:

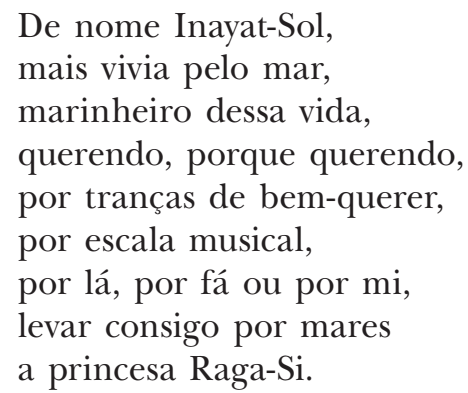

6. ARRABAL, José. A princesa Raga-Si. Ilustrações de Cláudia Scatamacchia. São Paulo:

Paulinas, 1999.

7. SANTELLA; NÖTH, Imagem, op. cit., p. 55.

\section{ARRABAL E SCATAMACCHIA: O TEXTO DA IMAGEM E A IMAGEM DO TEXTO}

A relação texto/imagem foi analisada enquanto signos indexicais. Conforme Santaella e Nöth: "Na relação de relais, o texto e a imagem se encontram numa relação complementar. As palavras, assim como as imagens, são fragmentos de um sintagma geral e a unidade da mensagem se realiza em um nível mais avançado"?.

A relação entre o texto e a imagem em A princesa Raga-Si faz com que a atenção do leitor se concentre na mesma medida - indo da imagem para a palavra e da palavra para a imagem -, e ambas mantendo suas funções semânticas. 
O livro é ilustrado em páginas duplas, numa profusão de cores suaves e tons pastéis, de traços delicados e linhas onduladas. A moldura se apresenta em estilo ornamental, florida e rebuscada, configurando um ambiente palaciano que nos remete aos contos orientais. Assim, também, são as linhas que traçam os olhos das personagens: mostram-se alongadas em tonalidade forte, identificando o modelo estético do povo hindu.

Profusamente coloridas, as imagens vão desfiando as emoções descritas no poema: medo, solidão, hesitação, esperança, admiração, descoberta. Repletas de informações, as cores vão assumindo significados simbólicos: o branco das vestes de Raga-Si produz o efeito do silêncio absoluto, mas, também, "O branco - candidus - é a cor do candidato, i.e., daquele que vai mudar de condição". As vestes de Inayat-Sol são amarelas, cor da juventude e do vigor. Ele usa na cabeça um turbante alaranjado e uma peça drapeada da mesma coloração, que passa pelo ombro e cai pelas pernas. O laranja, em muitas culturas, é a cor da fecundidade, e a oferenda de laranja às moças significava um pedido de casamento. As cores, nessa obra, são o elemento visual mais forte que indicia o estado emocional de Raga-Si: do lilás da solidão ao intenso verde do despertar para a vida.

Percebe-se textura nas molduras das imagens. Traços sinuosos e esvoaçantes como o vento em um bosque de salgueiros. São 31 ilustrações e o livro não é paginado. A capa já nos conta a lenda, apresentando Raga-Si com um sorriso tal qual o da Gioconda. A princesa acaricia um pássaro, formando um círculo com as mãos, onde está impresso o título do livro. Após a página da dedicatória, Raga-Si traz nas mãos o algodão, ainda em flor, símbolo do silêncio, indicando a vida reclusa da princesa.

Na ilustração seguinte, Raga-Si está acomodada num almofadão, cercada de um instrumento de corda, dois jarros, um fruto similar à abóbora ${ }^{9}$ e uma fruteira com damascos. Fascinante mesmo é encontrar nessa ilustração uma metáfora criada a partir de uma imagem: um belo pássaro na gaiola e os versos do escritor:

Se consigo, só, vivia,

nada mais acontecia.

Na seqüência, encontra-se o casal em páginas opostas, tal qual o Sol e a Lua, em cores contrastantes: quente e fria, vivo e adormecida; ele, o dia, e ela, a noite.

Na página seguinte, temos indícios da mudança que está por vir: ali, ao lado de uma Raga-Si soturna, está um pavão: símbolo da transmutação.

\section{O POEMA PARA SER CANTADO E A REPETIÇÃO}

O texto vem em forma de poema, com estrofes irregulares, ora em versos rimados, ora em versos brancos. Porém, o recurso da repetição, empregado com inteligência e gosto, traduz a energia significativa desse canto (o grifo é nosso):
8. CHEVALIER, Jean; GHEERBRANT, Alain. Dicionário de símbolos. Tradução de Vera da Costa e Silva et al. 17. ed. Rio de Janeiro: José Olympio, 2002. p. 141.

9. "Serei uma cabaça, condenada a ficar dependurada sem que ninguém a coma?" (dito chinês). 
comunicação \& educação • Ano XIII • Número 3 • set/dez 2008

\begin{abstract}
Enquanto tudo na praça, tudo, tudo, lhe aguardava por dia que mais viesse e ela por mais se abrisse dessa sua guardação.

$[\ldots]$

$\mathrm{E}$ assim, mais sem viver

E mesmo mais sem viver, Seu branco ia perdendo.
\end{abstract}

\title{
O CEGO, A SINESTESIA E A MOLDURA
}

Nesse momento, a imagem se ancora no texto para qualificar o estado de cegueira da personagem, pois na ilustração há somente um índice: o bastão. O cego não tem nome, e suas vestes são tintadas em gradação do branco para o azul, do azul para o cinza. Barba longa e afilada, ele simboliza o mundo espiritual em que os olhos físicos, fechados ao exterior, podem perceber a luz divina. É ele quem conduz Raga-Si às ruas da vida.

Doravante, o mundo de Raga-Si tem cheiro, paladar, tato e muita sensibilidade. A sinestesia toma conta das palavras e das imagens. As cores tornamse mais saturadas, mas os traços continuam elegantes e delicados. O poema converge com o cenário: as palavras são escritas entre os ângulos das árvores, nas águas do lago, nos ramos das árvores com fruto. $\mathrm{O}$ olho do leitor não faz mais os movimentos convencionais, entretanto, ainda permanece a harmonia entre imagem e palavra.

Até o encontro com o cego, as ilustrações foram emolduradas com traços retos e fortes e, embora não asfixiem a imagem, o cenário é delimitado; contudo, à medida que o cego vai desvelando o mundo para Raga-Si, os traços retos dão lugar às linhas curvas e circulares, desembocando no horizonte infinito e na saliência das falésias à beira-mar. A moldura, também, conta a lenda.

\section{A RELAÇÃO ENTRE IMAGEM E TEXTO EM A PRINCESA RAGA-SI}

Nesse poema, a imagem e o texto têm a mesma importância: ora o texto está integrado à imagem, ora a imagem está integrada ao texto. Essa disposição lado a lado possibilita diversas leituras, criando um jogo de códigos que se imbricam, combinam-se, encontram-se, mas que sustentam o prazer de ler de um modo mais atento para descobrir novas formas interpretativas dentro dessa colméia que constitui a Semiótica.

Então...

Neste mundo redesenhado pela internet, onde as relações se estabelecem no signo www (wide world web), explicá-lo à luz da Semiótica de Peirce pode significar o aparecimento de um novo homem pensador. 
Para este mundo que se reinventa a todo instante, analisá-lo dentro das teorias peirceanas nos leva a imaginar uma nova relação entre os saberes, em que o conhecimento sai do território compartimentado para se estabelecer no espaço da transdisciplinaridade. Assim, é possível conceber uma outra relação entre Ciência, Arte e Fé.

A tríade de Peirce e suas categorias formais - primeiridade, secundidade e terceiridade - têm uma dimensão espantosa, cuja abrangência não se mede pela aplicabilidade às mais diversas áreas do conhecimento, mas porque admitem, sem ranços, modos plurais de ver e inferir em um mundo que foi criado $\mathrm{com}$ o homem e não para o homem.

\section{REFERÊNCIAS BIBLIOGRÁFICAS}

ARRABAL, José. A princesa Raga-Si. Ilustrações de Cláudia Scatamacchia. São Paulo: Paulinas, 1999.

CHEVALIER, Jean; GHEERBRANT, Alain. Dicionário de símbolos. Tradução de Vera da Costa e Silva et al. 17. ed. Rio de Janeiro: José Olympio, 2002.

PEIRCE, Charles S. Os pensadores. São Paulo: Abril Cultural, 1974. vol. XXXVI.

SANTAELLA, Lucia. A assinatura das coisas: Peirce e a Literatura. Rio de Janeiro: Imago, 1992.

SANTELLA, Lucia; NÖTH, Winfried. Imagem: cognição, semiótica, mídia. 3. ed. São Paulo: Iluminuras, 2001. 